\title{
京町家様式の化粧軒裏の各部仕様が火災時の遮熱・遮炎性能に及ぼす影響 \\ INTEGRITY OF BARE TIMBER EAVES/WALL INTERFACE OF KYOTO-STYLE TRADITIONAL TOWNHOUSE AGAINST EXTERNAL FIRES
}

\author{
安井 昇*, 長谷見 雄二**, 清水 真理子***, 木 村 忠 紀****, 田 村 佳 英***** \\ Noboru YASUI, Yuji HASEMI, Mariko SHIMIZU, \\ Tadanori KIMURA and Yoshihide TAMURA
}

\begin{abstract}
Integrity of bare timber eaves characterizing Kyoto-style traditional townhouses against external fires is examined by experiments using different design details for "Mendo" board, the joint between the beam and the roof. The experiments show significant improvement of the integrity by the use of plaster or soil on either side of the "Mendo" board, or by increasing the thickness of the "Mendo" board. Although the bare timber eaves has been long considered the main drawback of the Kyoto-style townhouses with regard to fire safety, the study has revealed that code-acceptable integrity can be achieved without introducing any industrial fire retardant agents.
\end{abstract}

Keywords : traditional town house, eaves, bare timber, thermal insulation, integrity 伝統町家、軒裏、木材現し、遮熱性、遮炎性

1.はじめに

京町家の屋根形状は、建物の奥行方向に屋根が架かる切妻で、玄 関は平入りとなるため、道路面に必ず軒裏が存在する。京町家の ファサードの軒裹周辺は、図1のように木材の析梁・垂木・野地 板・面戸板で構成され、その全てが露出する “化粧軒毫”之なっ て、外観意匠上、重要な役割を担っている。このため、町家正面の 外壁の防火性能を土塗壁の洛り厚の確保等で向上させたとしても1)、 この化粧軒裏が延焼防止上、大きな弱点になると考えられてきた。

さて、京町家様式の化精軒裏を詳しくみると、栴梁の上に、垂木 を載せることによって生じる饰梁と野地板の隙間を面戸板で塞ぐ構 造となっており、それぞれの部材寸法は、垂木が $40 \sim 45 \mathrm{~mm}$ 角、 面戸板が $9 \sim 15 \mathrm{~mm}$ 厚程度、野地板が $9 \sim 12 \mathrm{~mm}$ 厚程度と比較的 小さく、また、薄い部材が使用されている。このため、化粧軒裹 は、一旦着火すると軒裹面で燃え広がる可能性があり、防火性能に ついて、以下の弱点があると予想できる。

(1)出火建物開口部からの噴出火炎が軒裏を析行方向に流れて隣接 建物に延焼させる。

（2)外部火炎時に面戸板や野地板上部を通じて、外部から建物内部 に延焼させる。

これらの弱点の対策として、過去, 京町家の軒下にドレンチャーを
設置して建物への着火を防止する方法が夷験的に検討されている2)。 しかし、京都等の歴史的市街地全体にドレンチャーを整備していくの は困難なうえに、動力を必要とする防災設備では、放水が必要な箇所 のみを機能的に作動させるための操作、地震等で水道・電力が停止 した場合の対策等に容易には解決し難い課題を残すと考えられる。

ここで、軒裏の燃焼が隣接建物に及ぼす延焼危険の内容を具体的 に考察すると、軒裏そのものが燃えても火炎面はさほど大きくな

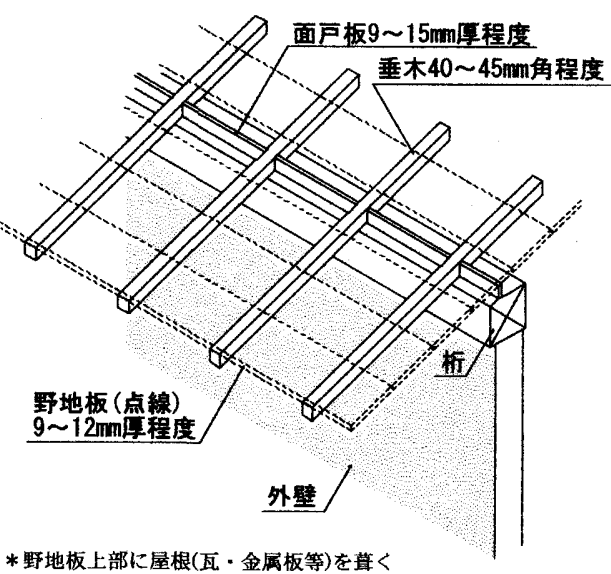

図 1 京町家様式の一般的な化粧軒裹の構成
* 早稲田大学理工学総合研究センター 客員研究員 - 博士 (工学)

** 早稲田大学理工学部 教授・工博

****住友林業(侏) 研究員

(実験当時 早稲田大学理工学研究科 大学院生)

**** 京都府建築工業協同組合 副理事長

******関西木造住文化研究会 代表幹事
Visiting Researcher, RISE Waseda University, Ph. D.

Prof., School of Science and Engineering, Waseda University, Dr. Eng. Researcher, Sumitomo Forestry Co.

(Formerly Graduate Student, Waseda University)

Vice Chairman, Kyoto Cooperative Union of Carpenters

Secretariat, Kansai Association for Research in Traditional Housings 
く、また燃焼時間もさほど長くないから、例えば、ファサードの軒 裹が然えても実質的に延焼の韋威を及ぼす可能性があるのは、道路 対向側ではなく、当該建物雨側の建物の軒裏に対してである。屋根 卯建や袖卯建等は、軒裏を介して隣接建物に延焼するのを防止する 対策としてよく知られているが、建物の外周部材が屋内への延焼を 防止する性能を有していれば、化精軒毫が然え広がっても、屋内へ の延焼は防止でき、市街地火災等の大規模火災に至る可能性は小さ いはずである。建築基淮法では、この考えのもとに、延焼のおそれ のある部分の軒㙜について、上記(2)の外部から建物内部への延芜防 止性能のみを要求している。即ち、軒裏が然えることに防火安全 上、全く問題がないわけではないが、市街地火災の発生の可能性に 対しては、軒裏から屋内に延焼することによって建物本体が炎上す ることが問題の核心なのであり、軒裏そのものを木造とすること が、法令上、特に問題にされているわけではないと解される。ま た、近年の歴史的市街地での京町家の娍少は、京町家の外周部の各 部位が法令適合しておらず3), 新築や大規模改修ができないこと も、その一因である。その状況を鑑み、本研究では、京町家様式の 化栍軒毫について、実大試験体を使った加熱実験により、軒毫を構 成する部材の各部仕様が、外部から建物内部への延焼防止性能に及 ぼす影䈏を系統的に検討し、法令適合可能な化粧軒赛の仕様を明ら かにすることを目標とした。

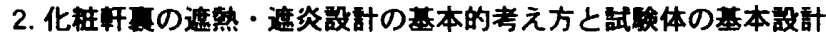

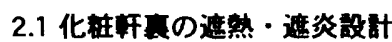

化粧軒婁は建物の構造耐力を支持する部材ではないため、建築基 準法の概念に基づく建物外部から内部への延焼防止性能は遮熱性と 遮炎性である。特に建物内部への延焼が危惧されるのは、図 2 のよ うに、面戸板周辺や野地板上側である。部材の木材厚が薄いと火炎 貫通しやすかったり、部材同士の接合部が防火上の弱点になること

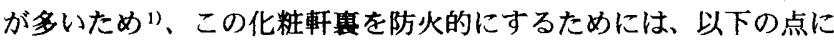
配慮する必要がある。

（1)面戸板が薄いとその部分から容易に建物内部に延焼するため、 十分な厚さを確保する。

（2）野地板が薄いと、軒裏の野地板が燃え抜け、野地板・屋根草き 材間の隙間を燃え扰がって小屋塞（室内）へ延焼するため、十 分な野地板厚さを確保するか、野地板と屋根苦き材の隙間で燃 え桩がらない措置を講じる。

(3)面戸板・垂木等の部材の接合部に生じる隙間から火炎貫通する ため、隙間が生じにくい納まりにしたり、土・漆喰等を知間を 塞ぐように充填する。

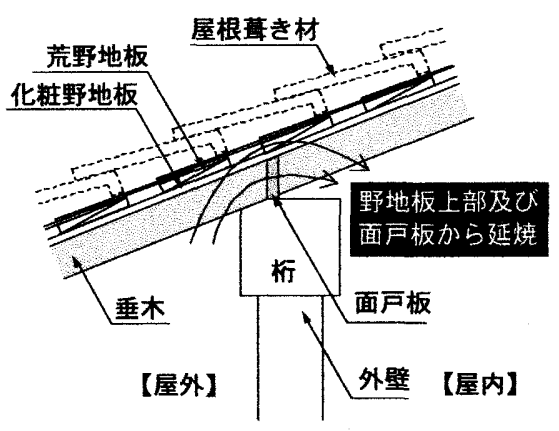

図 2 化粧軒裹の延焼経路概念図
然え代設計に使用される木材の炭化速度の慣用値は $0.6 \mathrm{~mm} /$ 分 $^{4)}$ であり、材寸が小さいと炭化が加速されるとしても、防火構造に必 要な 30 分間の加熱では、概ね $30 \mathrm{~mm}$ の炭化を想定すればよい。 従って、木材外部側の表面から $30 \mathrm{~mm}$ 程度は炭化するものとして、 それに、荷重支持や遮熱性稚持のための断面増加を行えば、化粧軒 裹から建物内部への延焼を防止できよう。また、京町家様式の丁寧 な仕事では、面戸板外側への漆喰の塗り込みや垂木の面戸欠きが昔 から行われている。これらは、面戸板の遮熱性の向上効果だけでな く、面戸板・垂木等の部材の接合部に生じる隙間からの火炎貫通を 防止する効果も期待できる。この隙間からの火炎貫通を予防すると いう意味では，漆喰を面戸板の屋外側に塗る伝統的仕上げに加えて、 室内側に塗ることも有効と考えられる。

ところで、防火補強の手段としては、不然性能の高いボード類・ 難燃薬剤を含侵した木材の使用や、木材への防火塗料の塗布等も考 えられるが、京町家等の伝統的な木造建案汢、大工棟梁や比較的小 規模な工務店によるオープン工法として施工されているため、でき るだけ、生産方法や市場が開放されている木材や土・漆喰等の一般 的な材料のみを使用することを前提とした。

\section{2 試挽体の基本設計・憋作}

試験体仕様一臨を表 1 に、試験体の構成を図 3 に、また各試験体 の詳細仕様を図 4 に示す。試験体は、性能評価機関の「防耐火性能 評価・業務評価方法書」5)をもとに、軒震部分の延焼防止性能が確認 できる構成とし、様々な仕様を同時に検討できるよう一試験体に複 数の仕様を盛り込んだ。屋根苜き材は、珪酸カルシウム板で代用 し、試験装置の安全管理上、屋外部分の垂木と野地板が燃焼により 耐力を失っても、屋根苒き材は落下しないように設計した。また、 本実験で再現しようとする加熱が、珪酸カルシウム板の有無にかか らわず一定になるように、実験中の加熱温度を面戸板近傍（約 $10 \mathrm{~cm}$ 離れた位置）の温度で制御することとした。

実験は、防火的な軒裹を開発する過程によって、大きく 2 つの段 階に分けられる。まず、第一段階は、延焼防止性能を有する化粧軒 裏を実現する見通しをつけるために、1体ずつ、試験体の設計と実 験を繰り返し、実験の結果を踏まえて仕様に改良を加えた（表1の 試験体 $\mathrm{A} \sim \mathrm{C}$ )。これら試験体で、建築基準法上、軒颗に要求され

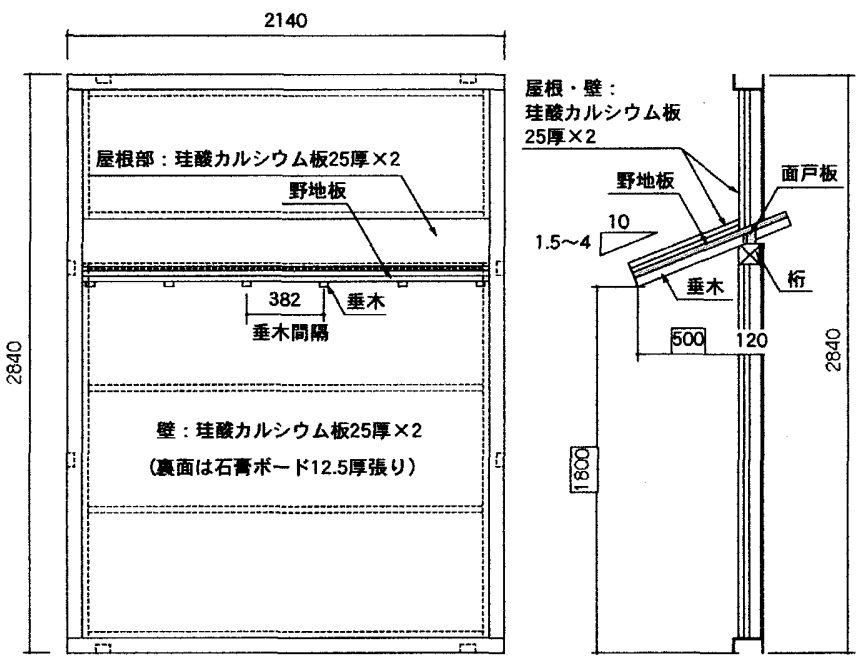

図 3 試験体の構成（単位：mm) 
る最高水潐の 1 時間淮耐火構造を実現できる見通しがたったため、 第二段階として、軒裹の各部仕様が延焼防止性能に与える影響を検 討するために、以下の項目を系統的に変化させて試験体の設計を 行った（試験体 $\mathrm{D} \sim \mathrm{H}$ )。

(1)面戸板の厚さと仕様

(2)野地板の厚さと重ね張りの有無

(3)垂木の断面寸法

(4)屋根勾配

(5)野地板と屋根惪き材の隙間の有無

(6)施工状況（新築または改修）

\section{(1)試験体設計の共通事項}

・面戸板に土や漆喰を塗る仕様では、経年変化で漆喰等が容易に脱

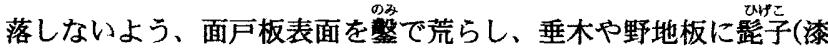
喰等と木材の接着性を向上させるために用いる麻紐）打ちをして から溙喰や土（含水率は5\%以下になるよう調整した）を塗った。 これは、火炎加熱時の脱落防止にも役立とう。

- 野地板は、木材の炭化寸法を考慮して、基本的に $30 \mathrm{~mm}$ 厚一枚張 りとした。ただし、野地板の重ね張りの影響をみるための試験体 $\mathrm{D} \cdot \mathrm{E}$ では、 $15 \mathrm{~mm}$ 厚二枚張り、野地板が薄い場合の延焼防止策 を検討する試験体 Iでは、12mm 厚一枚張りとした。
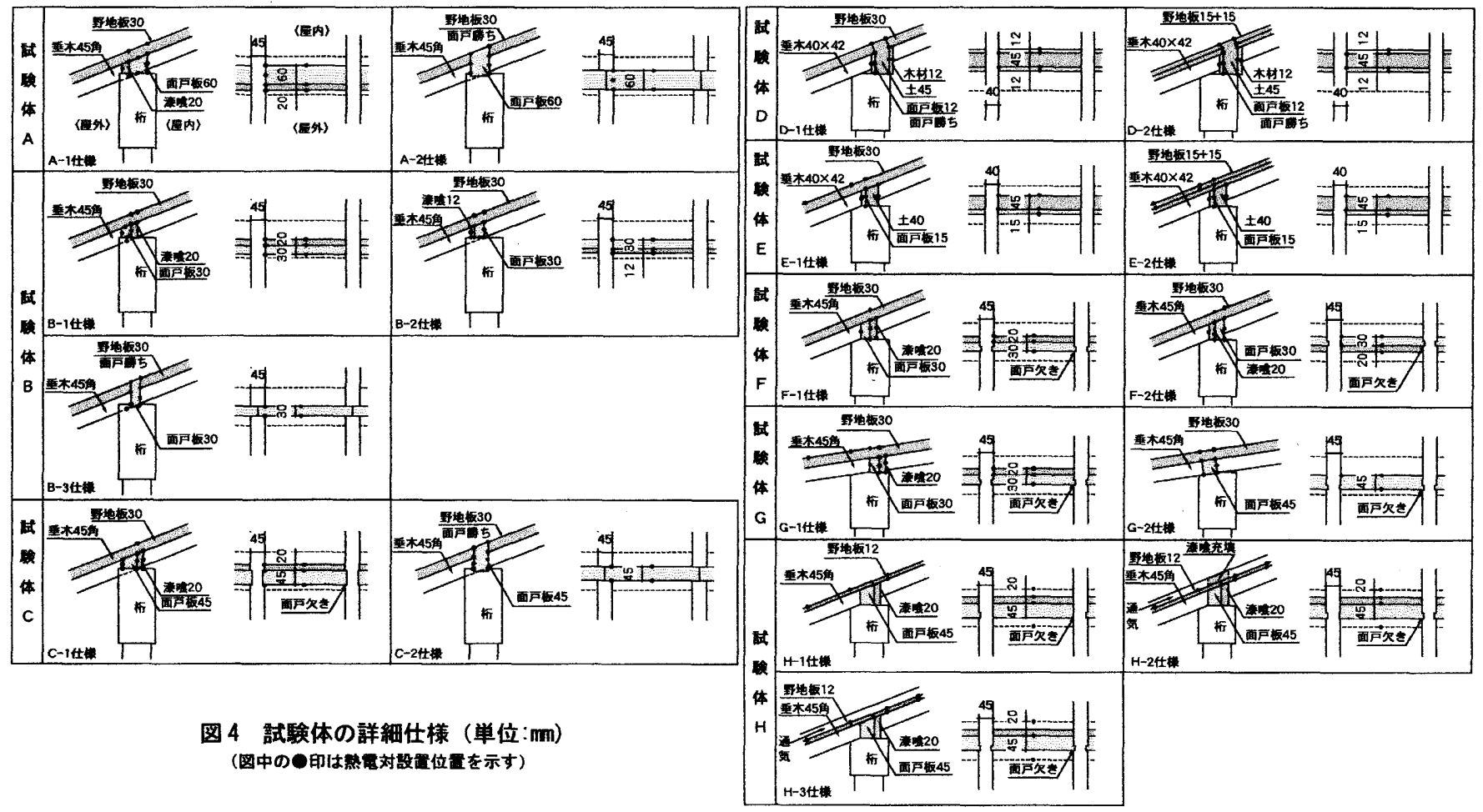

表 1 試験体仕様及び結果一覧

\begin{tabular}{|c|c|c|c|c|c|c|c|c|c|c|c|c|c|c|c|c|c|c|c|c|}
\hline \multirow{2}{*}{\multicolumn{2}{|c|}{ 比讙体 No }} & \multicolumn{3}{|c|}{ 第地报 } & \multicolumn{3}{|c|}{ 面已粄 } & \multicolumn{3}{|c|}{ 重木 } & \multicolumn{3}{|c|}{ 杬 } & \multirow{2}{*}{ 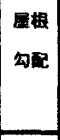 } & \multirow[t]{2}{*}{ 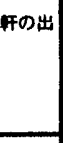 } & \multirow{2}{*}{ 加国 } & \multicolumn{3}{|c|}{ 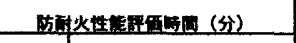 } & \multirow{2}{*}{$\begin{array}{l}\text { 防酎火 } \\
\text { 而国 }\end{array}$} \\
\hline & & 西さ & 蚁まり* & 上 & 木部 & 加慗相 & 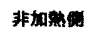 & 寸法 & 周雨 & 面年欠 है & 寸法 & E末の & 面戸板の & & & & 兴性 & 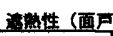 & S1: & \\
\hline \multirow[t]{2}{*}{ AL } & $A-1$ & 30 & 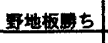 & SL & 60 & 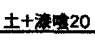 & a & $45 \times 45$ & 382 & \& & $120 \times 240$ & 重木欠光 & 突をつけ & $4 / 10$ & 500 & 30 & $=$ & - & $-(101 c)$ & 60 \\
\hline & $A-2$ & 30 & 面尸諳5 & ta & 60 & Es & sL & $45 \times 45$ & 382 & tac & $120 \times 240$ & 重本欠克 & $\times 60 \mathrm{~L} p<1$ & $4 / 10$ & 500 & 60 & 42 & 44 & 47 & 42 \\
\hline \multirow[t]{3}{*}{ B } & $B-1$ & 30 & 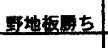 & 姚 & 30 & tes & 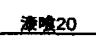 & $45 \times 45$ & 382 & 轧 & $20 \times 240$ & 拝杴光 & 资をつけ & $4 / 10$ & 500 & 45 & 41 & 12 & 14 & 12 \\
\hline & $8-2$ & 30 & 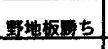 & ac & 30 & 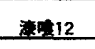 & se & $45 \times 45$ & 382 & tal & $120 \times 240$ & 重杴它 & 突类つ付 & $4 / 10$ & 500 & 45 & 31 & 27 & 27 & 27. \\
\hline & B-3 & 30 & 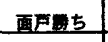 & 加 & 30 & ac & ac & $45 \times 45$ & 382 & ta & $120 \times 240$ & 重木久竞 & $x 30 L+y$ & $4 / 10$ & 500 & 15 & 25 & - & $-\left(97^{\circ} \mathrm{C}\right)$ & 25 \\
\hline \multirow[t]{2}{*}{$c$} & $c-1$ & 30 & 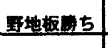 & 女L & 45 & 生 & 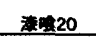 & $45 \times 45$ & 382 & $5 \times 45$ & $120 \times 240$ & 垂木欠委 & 哭芼つけ & $4 / 10$ & 500 & 60 & - & - & $-\left(93^{\circ} \mathrm{C}\right)$ & 60 \\
\hline & $c-2$ & 30 & 面巨舴与 & なL & 45 & sc & ac & $45 \times 45$ & 382 & \$ & $120 \times 240$ & 重本页老 & $9 \times 45 L+<0$ & $4 / 10$ & 500 & 60 & 41 & 17 & 18 & 17 \\
\hline \multirow[t]{2}{*}{ D } & $0-1$ & 30 & 面届与 & AL & 12 & 死 & $\pm 45+末 12$ & $40 \times 42$ & 382 & tac & $120 \times 180$ & 加欻光 & 突老つけ & $4 / 10$ & 500 & 60 & $=$ & - & $-(570)$ & 60 \\
\hline & D-2 & $15+15$ & 面已旬前 & ac & 12 & ac & $\pm 45+\ldots 12$ & $40 \times 42$ & 382 & ac & $120 \times 180$ & 上力ト久欠 & 㔖老つけ & $4 / 10$ & 500 & 60 & $=$ & - & $-(54 \tau)$ & 80 \\
\hline \multirow[t]{2}{*}{$E$} & $E-1$ & 30 & 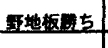 & ta & 15 & tac & \pm 40 & $40 \times 42$ & 382 & 杫 & $120 \times 180$ & 上カ以矢老 & 等毒つ什 & $4 / 10$ & 500 & 60 & - & - & $-(72 x)$ & 80 \\
\hline & $E-2$ & $15+15$ & 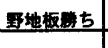 & な⿻ & 15 & Ix & \pm 40 & $40 \times 42$ & 382 & ts & $120 \times 180$ & 上力比者 & 笑老つけ & $4 / 10$ & 500 & 60 & - & - & $-\left(65^{\circ} \mathrm{c}\right)$ & 60 \\
\hline \multirow[t]{2}{*}{$F$} & $F-1$ & 30 & 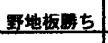 & a & 30 & al & 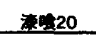 & $45 \times 45$ & 382 & $5 \times 15$ & $120 \times 180$ & 上加久党 & 乫老つけ & $4 / 10$ & 500 & 60 & - & - & $-\left(74^{\circ} C\right)$ & 60 \\
\hline & $F-2$ & 30 & 正地板到5 & tal & 30 & 造请20 & ta & $45 \times 45$ & 382 & $5 \times 15$ & $120 \times 180$ & トカト久光 & 实老つけ & $4 / 10$ & 500 & 80 & $=$ & $=$ & $-(62 \tau)$ & $\infty$ \\
\hline \multirow[t]{3}{*}{$\mathbf{G}$} & $G-1$ & 30 & 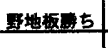 & sc & 30 & tac & 䊝 & $45 \times 45$ & 382 & $5 \times 15$ & $120 \times 180$ & 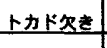 & 突をつけ & $1.5 / 10$ & 500 & 60 & - & - & $-\left(75 x^{\circ}\right)$ & 60 \\
\hline & a-2 & 30 & 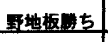 & 如 & -45 & tes & tal & $45 \times 45$ & 382 & $5 \times 15$ & $120 \times 180$ & 上カトイ娄 & 突老つけ & $1.5 / 10$ & 500 & 80 & 54 & - & $-\left(92^{\circ} \mathrm{C}\right)$ & 54 \\
\hline & $\mathrm{H}-1$ & 12 & 予地板致 5 & & -45 & tac & 20 & $45 \times 45$ & 382 & $5 \times 15$ & $120 \times 120$ & 上カト次老 & 突書つけ & $4 / 10$ & 500 & 45 & 20 & $=$ & $-(89 c)$ & 20 \\
\hline & $\mathrm{H}-2$ & 12 & 5 & 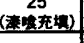 & 45 & Ac & 20 & $45 \times 45$ & 382 & $5 \times 15$ & $120 \times 120$ & 上カ上次光 & 突きつけ & $4 / 10$ & 500 & 45 & - & - & $-(48 c)$ & 45 \\
\hline & $\mathrm{H}-3$ & 12 & 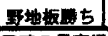 & 加 & 45 & \& & tetero & $45 \times 45$ & \begin{tabular}{|l|}
382 \\
\end{tabular} & $5 \times 15$ & $120 \times 120$ & 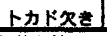 & 英党つけ & $4 / 10$ & 500 & 45 & $=$ & $=$ & $-(56 \mathrm{C})$ & 4 \\
\hline
\end{tabular}

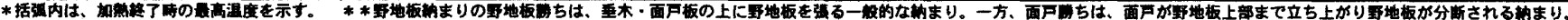

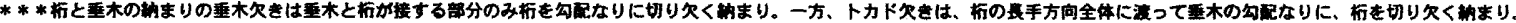

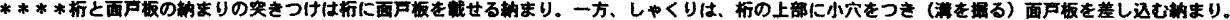


-垂木の寸法は、京町家の実状にあわせて、試験体D・Eが $40 \times$ $42 \mathrm{~mm}$ 、その他は $45 \times 45 \mathrm{~mm}$ とし、間隔は京町家の一般的な柱 芯々寸法（6尺3寸）の5等分の $382 \mathrm{~mm}$ とした。

・屋根勾配は京町家の実状にあわせて、瓦直きの一般的な勾配であ る4寸(4/10)とした。ただし、屋根勾配の影響をみる試験体 $\mathrm{G}$ は、金属板葨きで使われる 1.5 寸(1.5/10)勾配とした。

- 試験体材料は、京町家の一般的な仕様を考慮して、垂木、野地板、 面戸板をスキ材とした。枌梁は、アカマツ等が使用されることが 多いが、材料調達上の事情でベイマツとした。すべての木材は含 水率が $15 \%$ 以下になるよう調整し使用した。

\section{(2)各試験体の祥細仕様}

\section{【第一段階】}

延焼防止性能を有する化粧軒重を実現する見通しをつけるため に、1体ずつ、試䀶体の設計と実験を綝り返した。

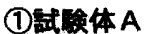

最初の試験体のため、部材断面寸法は、木材の炭化速度から考 えると若干大きめの面戸板 $60 \mathrm{~mm}$ 厚、野地板 $30 \mathrm{~mm}$ 厚とした。 面声部分の遮熱性を向上させるために漆喰を屋外側に塗った仕様 (A-1) と、遮炎性を向上させるために面戸板と野地板の納まりを 一般的な施工方法とは逆の面戸勝ちとする仕様(A-2)とした。

\section{(2)式験体 B}

試験体Aより、漆喰仕上げの効果は大きく、60 分を越える酎火 加熱に耐えることがわかった。しかし、町家正面を漺喰で仕上げ るには専門職の技術が必要なため、面戸板を $30 \mathrm{~mm}$ 厚とし、漆喰 を屋外側(B-2)に塗る仕様に加えて、屋内側(B-1)に塗る仕様を追 加した。

\section{(3)試験体 C}

試験体 B は、防耐火時間が 30 分に達しなかったが、垂木と面 戸板の接合部が突きつけでは、部材同士の知間が生じ易いため、 面戸板を $45 \mathrm{~mm}$ 厚とし、垂木に面戸欠きを施した。

\section{【第二段陼】}

武験体A〜Cにおいて、化精軒裏で延焼防止性能を確保できる見 通しがたった。試験体 D〜Hでは、軒裏の各部仕様が延焼防止性能 に与える影管を系統的に解明した。

\section{(4)試験体D}

改修時に屋根面からの施工が可能な仕様とし、既存の $12 \mathrm{~mm}$ 厚 の面戸板の裹面に土を $45 \mathrm{~mm}$ 充填した。野地板は、30mm一枚 張り (D-1)と $15 \mathrm{~mm}$ 二枚張り（D-2）とし、重ね張りの影響を 確認した。

\section{(5)試験体 $\mathrm{E}$}

改修時に屋根面及び屋内側からの施工が可能な仕様とし、 $15 \mathrm{~mm}$ 厚の面戸板の裏面に土を $40 \mathrm{~mm}$ 塗った。野地板は、 $30 \mathrm{~mm}$ 一枚張り $(\mathrm{E}-1)$ と $15 \mathrm{~mm}$ 二枚張り $(\mathrm{E}-2)$ とし、重ね張り の影響を確認した。

\section{(6)式験体 F}

試験体 $\mathrm{B}$ の改良仕様とし、30 $\mathrm{mm}$ 厚の面戸板はそのままに、弱 点となった面戸板と垂木の接合部に垂木の面戸欠きを設け、面戸 板の屋内側（F-1）及び屋外側（F-2）に漆喰を塗る仕様とした。

\section{(7)試験体 G}

屋根勾配が延焼防止性能に与える影響を検討するため、1.5 寸 勾配(1.5/10)とした。面戸部分は、F-1 仕様と同仕様 $(G-1)$ と、 木材の面戸板 $45 \mathrm{~mm}$ 厚のみの仕様(G-2)とした。ともに、面戸板 と垂木の接合部に垂木の面芦欠きを設けた。

\section{(8)試験体H}

面戸部分は、60 分以上の耐火加熱に耐える仕様(C-1)とし、野 地板の厚さの影響と、野地板と屋根苗き材の隙間の延焼防止手法 を検討した。 $12 \mathrm{~mm}$ 厚の野地板とし、野地板上部に隙間がない仕 様 $(\mathrm{H}-1)$ 、隙間がある仕様 $(\mathrm{H}-3)$ 、䅞間にファイヤーストップ 材として漆喰を充填した仕棣（H-2）とした。

\section{3. 実唤方法}

実鈳は、(財)日本建築総合試験所(試験体A,B,C,H)、(財)日本住宅・ 木材技術センター(試験体 D,E,G)、(財)建材試験センター中央試験所 (試酸体F)の壁炉を使用して実施した。

\section{1 加㙰方法}

加熱は、ISO834に規定する標淮加熱曲線に従って行った。可燃 材料で構成される化粧軒毫では、加熱開始から 10 分程度は試験体が 着火と消炎を䌍り返す。そのため、酎火炉内の温度制御は、加熱用 バーナーの然料供給を調整しながら、標浒加熱曲線に可能な限り一 致させるようにした。

\section{2 测定項目}

图 4 に示す位固（丸印）に $\phi 0.68 \mathrm{~mm} の \mathrm{~K}$ タイプ $(\mathrm{CA})$ 熱電対を最 大 58 点設置し、各部の温度変化を 30 秒間隔で計測した。また、遮 熱性能上の弱点部分を可視化するため、試験体非加熱面の温度分布 を赤外線サーモグラフィー䒾置(TVS-600P、测定温度 -20〜 1200 C、、日本アビオニクス社製）を使用して記録した。

\section{3 防涌火性能の評価}

軒裹の延焼防止に関する遮熱性・遮炎性について、文献 5)に従 い、それぞれ以下の基準で防耐火時間を決定することとした。

(1)遮熟性

面戸板毫面や垂木と面戸板の接合部近傍の温度が、平均温度(初期 温度 $+140^{\circ} \mathrm{C}$ )、もしくは、最高温度(初期温度 $+180^{\circ} \mathrm{C}$ ) を越えた 時間

(2)虺炎性

目視により、毫面(非加熱面)に火炎貫通が認められた時間

\section{4. 実験結果}

各試験体の実験結果一覧を表 1 （右側）に、加熱中の耐火炉内の 温度変化、主な面戸仕様ごとの面戸板周辺の温度変化、主な試験体 の加熱終了後の炭化状況をそれぞれ図 5〜図 7 に示す。

加熱中の試験体加熱面をみると、加熱開始 $2 \sim 3$ 分後に軒裏全体 に一気に着火し、消炎と着火を $2 \sim 3$ 回綝り返し、加熱開始 10 分頃 から燃焼が安定した。その後、20 分過ぎから、炭化した垂木や野地 板が落下し始め、30～40 分後には、加熱側のすべての垂木・野地 板が落下した。一方、非加熱面では、加熱開始後、しばらくの間、 


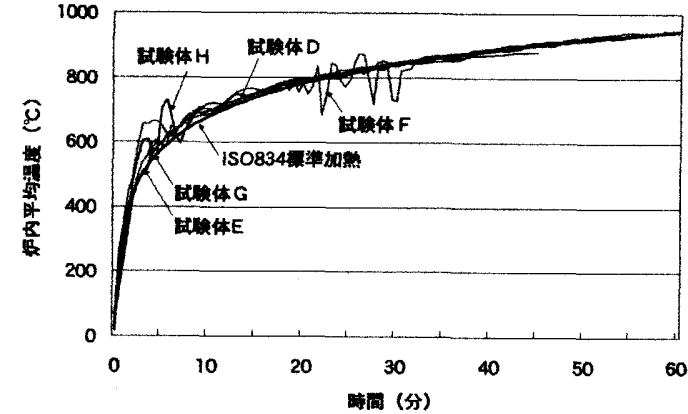

図 5 耐火妒内の温度変化

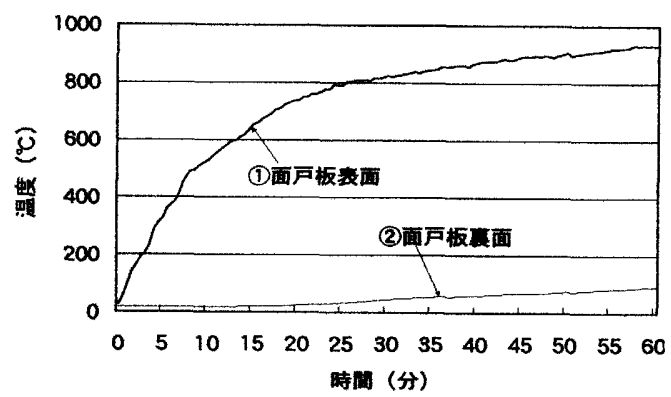

（1）木材 45mm 面戸板 (G-2 壮葙)

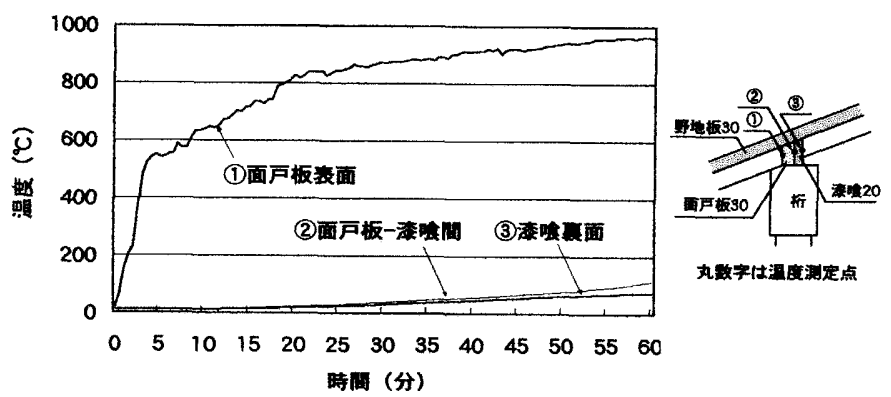

（2）木材 $30 \mathrm{~mm}$ 面戸板 + 裹面に洂喰 $20 \mathrm{~mm}$ 充填 ( F-1 仕様)

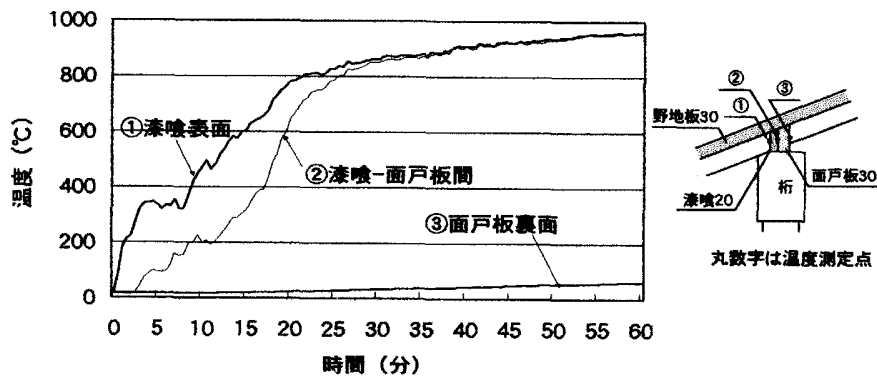

（3）表面に溙喰 $20 \mathrm{~mm}$ 乷 +木材 $30 \mathrm{~mm}$ 面戸板 (F-2 仕様)

図6 面戸仕様毎の面戸付近の温度変化

ほとんど変化がみられないが、火炎貫通が起こる5〜10 分前から、 垂木と面戸板の接合部周辺から湯気と思われる白煙が噴出し、その 後、一旦、火炎貫通が起こると、火炎が野地板下面に沿って一気に延 焼した。表 1 のように、試験体の設計と実験を綝り返した試験体 A〜 Cにおいて、加熱中に火炎貫通した仕様はあるものの、試験体 D H では、盛期火炎を想定した $30 \sim 60$ 分間の加熱に耐える仕様が明らか になった。

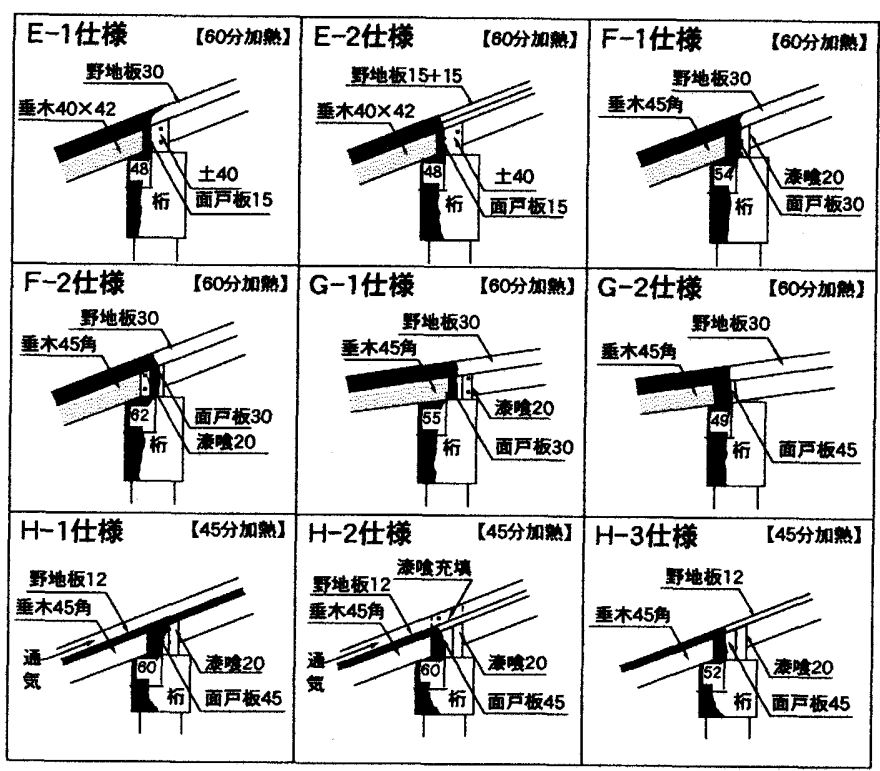

図 7 加熱終了後の灰化状況（単位:mm)

\section{5. 化社訐意の各部仕槏が延焼防止性能に与える影需 \\ 5.1 面戸部の仕様による影量}

本実験で用いた面戸仕様は以下の 3 種類に大別できる。

(1)木材のみの面戸板

(2)木材の面戸板虽面に隙間発生予防材として溙喰等を歭ったもの (3)木材の面戸板表面に防火被覆として漆喰等を塗ったもの 化粧軒裏の延焼防止を左右する要因を性能別に見ると、遮熱性は 火炎貫通がなけ扎ば、面戸板兾面の温度上昇が重要であり、遮炎性 は各構成部材の接合部の隙間予防が重要である。まず、遮熱性につ いて、図 8 の面戸仕様毎の面戸毫面温度変化をみると、いずれの仕 様も 60 分間の酎火加熱に対して、裏面温度は $100^{\circ} \mathrm{C}$ 以下となってお り、面戸部の仕様が木材単体もしくは木材と涂喰の組み合わせで、 計 $45 \sim 55 \mathrm{~mm}$ 厚あれば、面戸部分に 60 分を超える遮熱性がある ことがわかる。一方、遮炎性の向上には、垂木と面师の接合部の 隙間予防が特に重要であり、垂木に面戸欠きをしたり、面戸板の衰 面に漆喰を塗る工夫が有効である。以上をまとめると、遮熱性・遮 炎性を総合的に有する面戸部分の仕様は表 2 のようになる。

\section{2 野地板の仕漛による影需}

\section{(1)野地板席さの影需}

図 9 に、野地板厚 $30 \mathrm{~mm}$ と $12 \mathrm{~mm}$ の場合の野地板毫面(上面)の 温度变化を示す。これによると、野地板が $30 \mathrm{~mm}$ 厚の場合、野地板 裏面が木材の着火温度 $260^{\circ} \mathrm{C}$ に達するのは、加熱開始 49 分後であ る。一方、 $12 \mathrm{~mm}$ 厚では、約 15 分後であり、野地板の厚さが、野 地板毫面への燃え抜け防止に大きな影響を与えることがわかる。ま た、野地板の炭化速度を野地板毫面が着火温度に達する時間から推 測すると、 $30 \mathrm{~mm}$ 厚では $0.61 \mathrm{~mm} /$ 分、 $12 \mathrm{~mm}$ 厚では $0.80 \mathrm{~mm} /$ 分 と、板厚が薄いほど早くなる。

\section{(2)野地板と屋根真き材の嘹間の有無の影雷}

野地板の厚さが薄いと、野地板裹面への火炎貫通は早い時間に起 
表 2 面戸仕様による面戸部の防酎火時間

\begin{tabular}{|c|c|c|c|c|c|c|c|}
\hline \multicolumn{2}{|c|}{ 面户世杜 } & \multicolumn{3}{|c|}{ 要繁效策 } & \multicolumn{2}{|c|}{ 潼炎对策 } & \multirow{2}{*}{$\begin{array}{l}\text { 防种火時阔 } \\
\text { (分) }\end{array}$} \\
\hline & & 面声板 & 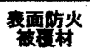 & 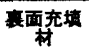 & 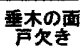 & 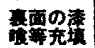 & \\
\hline 木㮏のみ & $G-2$ & 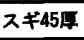 & - & - & 0 & - & 54 \\
\hline \multirow{3}{*}{ 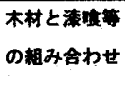 } & $F-2$ & ᄌ₹₹30/ & 淮20月 & - & 0 & - & 60 \\
\hline & $F-1, G-1$ & ᄌ₹キ3015 & - & 涞吸2015 & 0 & 0 & 60 \\
\hline & $\mathrm{E}-1, \mathrm{E}-2$ & スキ155 & - & $\pm 40 / 7$ & - & 0 & 60 \\
\hline
\end{tabular}

こるから、野地板と屋根惪き材間に隙間があると、その部分で上方 に延焼し、さらに、面戸板よりも屋内側で野地板を火炎貫通して小 屋裹へ延焼するおそれがある。図 10 に、野地板 $12 \mathrm{~mm}$ 厚で、野地 板と屋根㯰き材間に阥間がある場合とない場合の野地板裏面の温度 変化を示す。これによると、隙間がある場合、加熱開始 8 分後に木 材の着火温度 $260^{\circ} \mathrm{C}$ に達しており、腺間がない場合の約 15 分後よ りもかなり早い。野地板上部に腺間があるということは、実際の施 エでは、

\section{(1)瓦真き（栈莫き）屋根の場合}

(2)断熱層を野地板上部に設け、その上部に通気層をとる通気工法 の場合（屋根惪き材種類にはよらない）

が考えられるが、いずれも軒先は外部に開放されている。すなわ ち、火炎時には軒先から野地板上部の隙間に高温空気や火炎が侵入 し、烸間がない場合よりも早く野地板裏面の温度が上昇すると考え られる。そのため、野地板 $12 \mathrm{~mm}$ 厚でその上側に隚間があると、 加熱開始約 20 分後に小屋毫へ火炎が再貫通している（試験体H）。 一方で、野地板上部に隙間がない場合は、野地板が $12 \mathrm{~mm}$ 厚で あっても、45 分間の加熱に対して、遮熱性と遮炎性は十分に保た れた。

このように、野地板が十分に厚い場合 $(30 \mathrm{~mm})$ は、野地板上部の 隙間の有無が 60 分間の耐火加熱に対して、大きな問題となること はないが、 $12 \mathrm{~mm}$ 厚と薄い場合には、上部に隙間があると、容易に 隙間で延焼执大し、小屋軎へ再貫通する。その対策としては、野地 板上部の隙間の面戸板直上部分に漆喰等のファイヤーストップ材を 設けることが考えられる。図 11 に、野地板上部の隙間のファイ ヤーストップ材の有無による小屋裏部の野地板裏面温度変化を示 す。これによると、ファイヤーストップ材を設けることにより、野 地板上部での燃焼拡大を防止でき、十分にその手法が有効であるこ とがわかる。実施工で、野地板上部に隙間が生じるのは、「瓦蒀き の場合」と「屋根通気工法の場合」であったが、このファイヤース トップ材を設ける手法は、瓦㯰きには適用可能であるが、屋根通気 工法では、通気層を塞いでしまう。そのため、屋根通気工法におい ては、野地板厚さを $30 \mathrm{~mm}$ としたうえで、その上部に通気層を設 けるなど、野地板上部を介した屋内への延焼を防止する措置が必要 である。

\section{(3)野地板の重ね張りの影整}

図 12 に野地板厚さが $30 \mathrm{~mm}$ と $15 \mathrm{~mm}$ を二枚張りした場合の野 地板重面(上面)の温度変化を示す。これによると、野地板を $15 \mathrm{~mm}$ 厚二枚張りとした場合、野地板重面温度が、木材の着火温度とされ る $260^{\circ} \mathrm{C}$ を越えるのは、一枚目が約 25 分、二枚目が約 42 分であ る。一方、 $30 \mathrm{~mm}$ 厚一枚張りとした場合、野地板裹面温度は、約

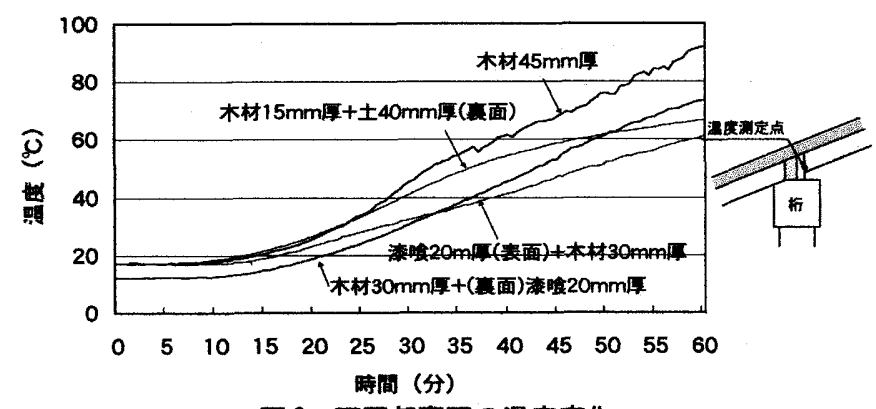

图 8 面戸部萋面の温度变化

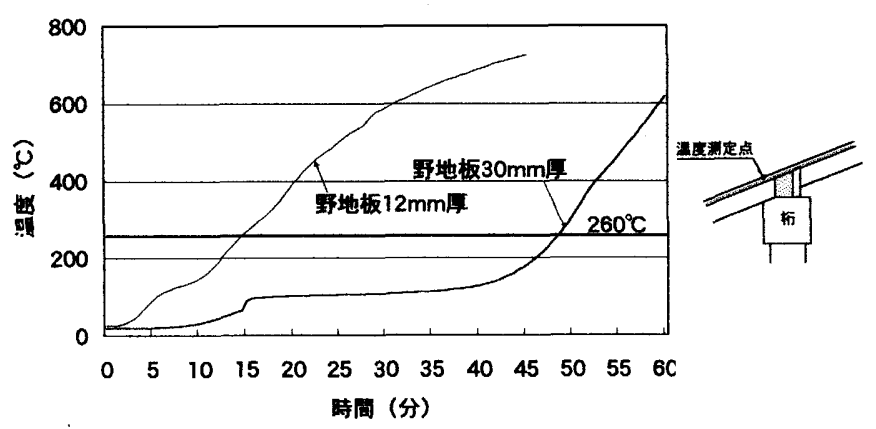

図 9 野地板の厚さによるの野地板上部の温度变化

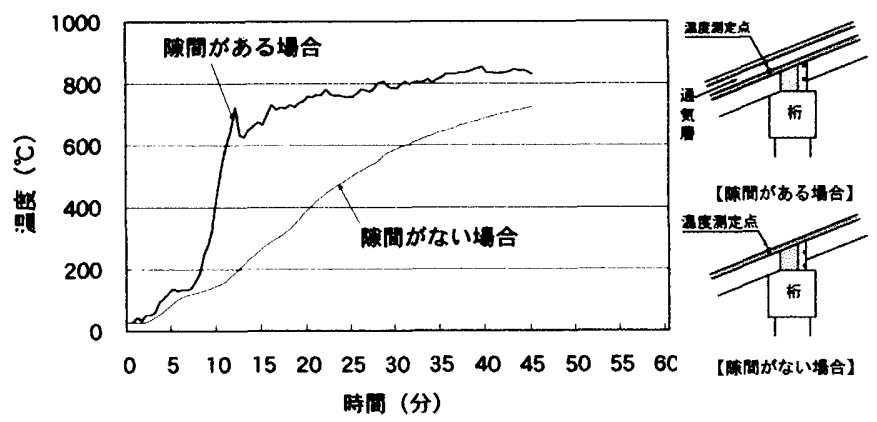

图 10 野地板上部の陵間の有無による野地板上部の温度变化

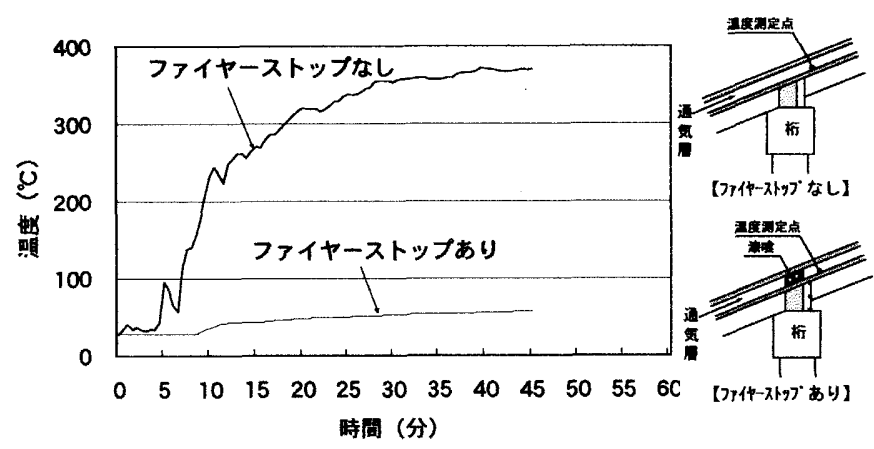

图 11 野地板一屋根苜き材の傹間のファイヤーストップ材 の有無による野地板上部の温度変化
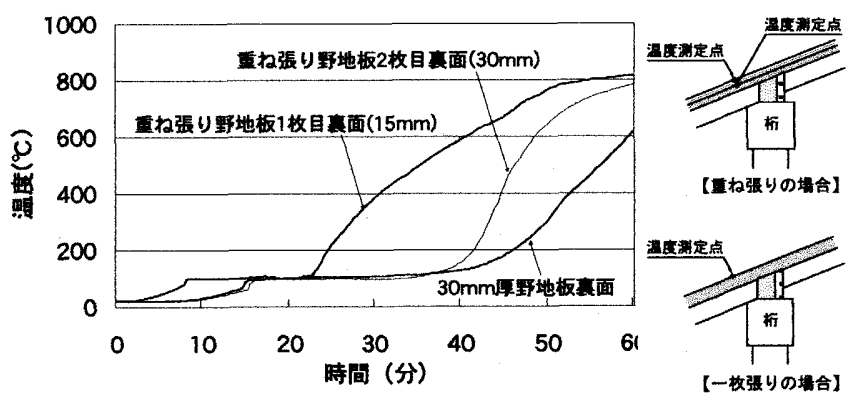

図 12 野地板の重ね張りの有無による野地板上部の温度変化 

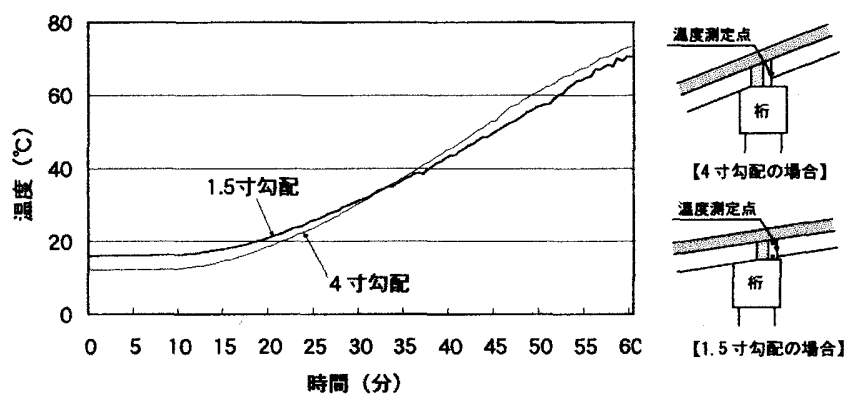

図 13 尿根勾配の違いによる面戸板襄面の温度変化

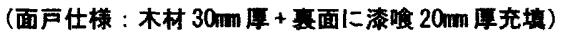

48 分で $260^{\circ} \mathrm{C}$ を越えており、若干、二枚張りのほうが、野地板裏面 に燃える抜ける時間が約早い。しかし、野地板上部に火炎貫通後、 屋内の小屋裏へ火炎が再貫通するには、さらに、同程度の時間を要 すると考えられ、準酎火構造に相当する $45 \sim 60$ 分間の加熱を考え ると、野地板の重ね張りが化精軒裏の延焼防止性能に与える影響は 少ないといえる。

\section{3 垂木の仕様による影管}

本実験では、京町家様式を想定して、一般に施工される垂木の断 面寸法の中では、比較的小さい $40 \times 42 \mathrm{~mm} 、 45 \times 45 \mathrm{~mm}$ を使用 した。一般に、部材断面が小さい方が部材全体の温度上昇が早く、 炭化速度が大きくなる。すなわち、垂木が今回の断面寸法以上であ れば本実跧と同等以上の延焼防止性能が期待できる。また、遮炎性 は垂木と面戸板の接合部の覙間予防が重要であったから、本実験の ように垂木の面戸欠きを設けるなど、面戸板・野地板等との接合を 確実にするか、面戸板に漆喰等を塗れば、垂木間隔は延焼防止性能 に大きな影響は与えないと考えられる。

\section{4 屋根の勾配寸法による影霓}

図 13 に面戸部及び野地板の仕様は同じで、屋根勾配のみ異なる 試験体 F-1 と G-1 の面戸板㘊面の温度変化を示す。これによると、 1.5 寸と 4 寸勾配では、面戸板裏面温度に大きな変化はみられず、 さらに、表 1 からも 60 分間の加熱時間中の火炎貫通はともにみら れない。これは、実験時の加熱温度を面戸板近傍の温度を基準とし て制御したため、面戸板表面が受ける加熱は勾配によらず一定で あったためと考えられる。すなわち、京町家の実施工で使われる屋 根勾配の範囲では、屋根勾配寸法が化粧軒裏の延焼防止性能に与え る影響は少ないといえる。

\section{5 材程による影霓}

本実験では、比較的炭化速度の大きい1),61なモ゙スギ材を使用した。 スギ材で、30〜 60 分の遮熱性・遮炎性が得られたため、京町家で 一般的に使用される材種の範囲では、材種が化粧軒裏の延焼防止性 能に与える影響は少ないと考える。

\section{6. まとめ}

京町家様式の化粧軒裏について、各部仕様が延焼防止性能に与え る影響を調べるために、実大試験体を使った酎火加熱実験を行い、
以下の知見を得た。

(1)垂木・野地板等が露出した化粧軒裏で、法令上、準耐火構造 60 分に相当する延焼防止性能を有する仕様が赛現可能である。

(2)化粧軒裏の遮熱性は、野地板が十分厚ければ、面戸部分の仕様に 支配される。

(3)化粧軒裏の遮炎性は、軒裏を構成する部材同士の接合部の䅞間の 有無に支配される。そのため、垂木の面戸欠きや漆喰を裹面から 充填するなど、隙間の生じにくい納まりとすることが有効である。 (4)野地板厚さが薄い場合は、野地板上部に延焼した後、小屋裏へ延 焼する。これを防止するには、野地板上部に隙間が生じない屋根 苜き材とするか、隙間にファイヤーストップ材を設ければよい。

(5)部材同士の隙間が生じにくい工夫をすれば、垂木の断面寸法や間 隔が化精軒裹の延焼防止性能に与える影響は少ない。 (6)屋根勾配が化粧軒裏の延焼防止性能に与える影響は少ない。 (7)材種が化粧軒裏の延焼防止性能に与える影響は少ない。

*注 $1:$ 平成 16 年国土交通省告示第 788～790 号により、裏返し筮りのない 土壁、化粧軒赛の防火構造・準耐火構造適合仕様が示されている。しかし、 これら告示は、本研究及び文献 1)で得られた実験結果に基づいたものである。

\section{尌辞}

本研究は、平成 $13 \sim 15$ 年度(財)旭硝子財団による研究助成「再生再 利用可能な長寿命市街地建築としての木造土壁構法の技術指針整備に関 する研究」、平成 13 年度農林水産省補助事業「木材産業技術害用化促進 㹂急対策事業小、平成 14 年度国土交通省委託による「都市における京町 家等伝統的工法による建築物再生・活性化方策検討調査小平成 15 年度 科学研究費補助金(基盤研究 B2、研究代表者: 室崎益輝)の一環として行 われた。実験にあたり、当時、早稲田大学長谷見研究室の秋月通孝氏、 馬屋原敦氏、大西卓氏、上島基英氏、酒井憲吾氏、桶山恭助氏、尾野克 典氏、関悠平氏、財)日本建築総合試験所の吉田正友氏、山本幸一氏、(財) 日本住宅・木材技術センターの山田誠氏、最上汯二氏、高田峰幸氏、(財) 建材試験センターの西田一郎氏、神戸大学の北後明彦助教授、京都府建 笻工業協同組合、並びに(株)東亜理科他の関俰各位に多大なるご助言・ ご協力を賜わりました。記して墚く感謝の意を表します。

\section{参考文献}

1)安井昇・長谷見雄二・秋月通孝・馬屋原敦 - 大西卓 -上島基英・ 㚼俊充・木村忠紀・田村佳英・村上博 : 木造土壁の各部仕様が防耐火 性能に及ぼす影響 日本建築学会環境系論文集，第 567 号， $\mathrm{pp} 7-13,2003.5$

2)岡村義徳・堀内三郎・十倉媇他 : 伝統的木造住宅における延焼防止に 関する研究(1)(2)(3) 日本建築学会学術講演梗概集 pp183-188 1995 年度

3)安井昇・長谷見雄二・田村佳英・木村忠紀 : 哖防火地域に建設可能な 京町家様式の外周部材の開発 日本建築学会技術報告集 第 20 号， pp135-140, 2004.12

4)中村賢一・宮林正幸 : 大断面木材の耐火性(1） 木材工業 Vol.40-12， pp3-7, 1985

5)例元ば、(財)日本建築総合試験所：防耐火性能試験・評価業務方法書 平成 14 年 3 月 26 日版

6)原田寿郎：木材の燃焼性および面火性能に関する研究、森林総合研究 所報 No.378，2000

（2005年10月 8 日原稿受理， 2005 年 12 月 2 日採用決定） 